\title{
Fantástico e alegoria em $A$ mão perdida na caixa de correio, de Ignácio de Loyola Brandão
}

\author{
Fábio Lucas Pierini
}

RÉSUMÉ: Cet article a pour but démontrer comment est-ce que le fantastique et l'alégorie sont-ils possibles dans un même récit, A mão perdida na caixa de correio, d'Ignácio de Loyola Brandão sans que l'un doive annuler l'autre.

PALAVRAS-CHAVE: Fantástico, Alegoria, Realismo Mágico, Afinidades Kafkianas, Literatura Brasileira Contemporânea.

De uma forma geral, o gênero fantástico pode ser definido como uma narrativa cujos acontecimentos, sejam eles sobrenaturais, insólitos ou frenéticos, confundem ou deturpam a concepção de realidade dos personagens envolvidos. Entretanto, é necessário apresentar, ainda que sucintamente, as principais teorias consultadas para este trabalho.

Uma das teorias mais famosas e também uma das mais criticadas acerca da literatura fantástica é a teoria estrutural de T. Todorov, em que o teórico búlgaro demonstra haver um mecanismo comum às narrativas fantásticas analisadas por ele em seu livro. Esse mecanismo é composto por três aspectos formais denominados verbal, sintático e semântico.

$\mathrm{O}$ aspecto verbal é dividido em enunciação (narrador) e enunciado (narração). Para Todorov, o narrador do fantástico deve ser representado, ou seja, um personagem envolvido com os fatos ou um narrador que focalize apenas a ótica dos personagens, possibilitando uma interpretação ambígua dos acontecimentos. A enunciação, que diz respeito ao corpo do texto, deve ser permeada de mecanismos que mantenham a ambigüidade da

Fábio Lucas Pierini é Mestre em Estudos Literários pela Faculdade de Ciências e Letras da Unesp, Câmpus de Araraquara-SP. 
leitura, como o tempo verbal imperfeito e locuções como "parecia que", "tive a impressão que", etc.

O aspecto sintático diz respeito aos pontos culminantes da narrativa (sustos, visões, revelações, desaparecimentos, aparições, etc.) e à irreversibilidade da leitura da narrativa fantástica, pois um embaralhamento da linha do tempo pode comprometer o sucesso da narrativa.

$\mathrm{O}$ aspecto semântico representa os temas da narrativa fantástica, que Todorov divide em temas do eu e temas do tu. Os temas do eu são as relações do personagem com seu mundo e os temas do tu as relações entre personagens.

Apesar de prática, a teoria de Todorov infelizmente circunscreve apenas narrativas escolhidas por ele, ou seja, aquelas que mantinham a hesitação tanto dos personagens quanto do leitor até o fim, ou seja, os fatos sobrenaturais, insólitos, etc. eram reais ou apenas um sonho ou um engano? Ele ainda afirma que a partir de Franz Kafka o fantástico estaria morto por causa dos fenômenos insólitos e sobrenaturais dentro de suas narrativas e que não suscitam qualquer hesitação. Ou seria substituída pela explosão da literatura de ficção científica, na qual os fenômenos são explicados pela existência de um meio (pseudo) científico que os gera.

Outra teoria é a da poética de Irène Bessière, segundo a qual haveria uma contradição entre real e sobrenatural, em outras palavras, proporcionando uma experiência imaginária dos limites da razão. Segundo a autora, o escritor da narrativa fantástica cria um universo que é um simulacro daquele em que o leitor vive, onde se passam fenômenos sobrenaturais, situações insólitas e outros acontecimentos dessa ordem apesar de eles aí serem também impossíveis. Em suas próprias palavras, Bessière resume:

A narrativa fantástica apresenta-se como a transcrição da experiência imaginária dos limites da razão. Alia a falsidade intelectual de suas premissas a uma hipótese extra-natural ou sobrenatural, de tal maneira que a motivação realista seja indissociável de um princípio de irrealidade. A justaposição de duas probabilidades externas, uma empírica, outra meta-empírica, igualmente inadequadas, deve sugerir a existência do que na economia da natureza e de uma supranatureza, não pode ser. (BESSIÈRE, 1974, p. 62)

Uma teoria mais recente em relação a essas duas últimas é a de Jacques Finné. No primeiro capítulo de seu livro, o teórico belga retoma vários outros colegas, dizendo que quase todos os seus antecessores cometeram o engano do catálogo temático: uma tarefa sempre cansativa e inacabada. Outro engano muito criticado por Finné é o fato de muitos críticos e teóri- 
cos considerarem como fantásticas apenas as narrativas que causam medo nada mais injustificável. Mais adiante, quando critica mais explicitamente outros teóricos, ele assume estar desconcertado diante da teoria de Todorov, pois apesar de ter tentado descobrir um mecanismo comum a todas as narrativas fantásticas, baseou toda sua teoria num número reduzido de obras pouco exemplares e valorizou demais o papel do leitor e da hesitação.

Para Finné, o elemento mais comum numa narrativa fantástica é o mistério: um acontecimento que pode, a princípio, não ter explicação, o que gera um primeiro vetor, por ele denominado vetor de tensão. Quando a explicação surge, um segundo vetor é gerado, o vetor de distensão. Finné considera a possibilidade de o vetor distensão (explicação para o mistério) figurar logo no início da narrativa eliminando da narrativa o vetor tensão. Neste segundo caso ele equipara, mas não tanto, tal narrativa ao feérico (conto de fadas), pois aí há um acordo entre autor e leitor de que fenômenos impossíveis no mundo real ali são cotidianos.

Tais teorias, ainda que muito tenham contribuído para a concepção de fantástico aplicada aqui para o conto de Ignácio de Loyola Brandão, foram concebidas levando em conta, na grande maioria das vezes, as narrativas de origem européia. A simples título de esclarecimento quero esclarecer que considero três verdadeiras vertentes da literatura fantástica: uma que é a original européia, que ouso chamar de "clássica”, já definida por inúmeros autores além dos já considerados aqui; uma segunda que é característica da literatura de horror e terror dos Estados Unidos, na qual criaturas inumanas habitam atrás de uma parede que separa duas realidades ou dimensões; e uma terceira, de origens latino-americanas, o realismo mágico, no qual imperam a criatividade do autor em busca de técnicas narrativas cada vez mais diferentes do usual, para dar ao seu texto o poder de distorcer a noção de realidade dos personagens e, às vezes, também do leitor.

Dessas três vertentes, as obras de vários autores brasileiros - entre eles Murilo Rubião, José J. Veiga, Péricles Prade e Ignácio de Loyola Brandão parecem se encaixar melhor na busca de técnicas narrativas cada vez mais impressionantes proposta pelo realismo mágico. Por essa razão, justifica-se a adoção de uma teoria que esclareça um pouco melhor o que é o realismo mágico, e a tipologia de Willian Spindler é a que me parece mais satisfatória.

O crítico inglês começa seu artigo (magic realism: a typology) esclarecendo que o termo realismo mágico foi criado nos anos 1920 na Alemanha pelo crítico de arte Franz Roh e que era atribuído originalmente à pintura e não à literatura. Tal fenômeno nessa arte se apresentava como uma reação aos excessos do expressionismo e visava demonstrar os objetos reais sob uma nova ótica.

Com a tradução do livro de Roh para o espanhol, o termo se difundiu 
pela América Latina e em pouco tempo já era aplicado à literatura. Em introdução ao seu livro "O reino deste mundo" (1949) Alejo Carpentier lançou as bases do que chamou real "maravilhoso americano", referindo-se aos prodígios naturais das terras americanas que as faziam tão diferentes das européias. Com o tempo, real maravilhoso e realismo mágico tornaram-se termos sinônimos e sua acepção poderia ser dividida em duas: uma primeira, que é a originalmente proposta por Roh, segundo a qual uma realidade seria artisticamente representada sob um ponto de vista incomum, mas sem transpor os limites dessa mesma realidade, apenas fornecendo ao observador ou leitor uma impressão de irrealidade; e uma segunda, que é empregada mais atualmente, de acordo com a qual uma narrativa apresenta dois pontos de vista diferentes: um racional e científico e outro crente na existência da magia.

Spindler coloca que ambas as acepções são inexatas porque deixam de fora várias das mais importantes obras do realismo mágico latino-americano. Por essa razão, ele redefine novamente essas acepções (tipologias), complementando duas e criando uma terceira.

O primeiro "tipo" de realismo mágico apontado por Spindler é o metafísico e brota da definição de Roh: por meio da técnica do estranhamento, o escritor induz o leitor a uma sensação de irrealidade diante de uma cena real e cotidiana, fazendo com que esta seja vista como nunca antes, sem no entanto transgredir os limites do real.

A segunda acepção é a de realismo mágico antropológico, na qual o narrador se encontra dividido entre duas diferentes óticas para encarar os fatos narrados, um realista e outro mágico. Em narrativas desse tipo colocam-se em pé de igualdade as crenças da população em estagnação e a ciência da elite modernizadora, afirmando-se a possibilidade de convívio, muitas vezes conflituoso, entre essas duas visões de mundo.

O realismo mágico ontológico é o terceiro e último dos tipos classificados por Spindler e é o que mais se adapta aos contos de Ignácio de Loyola Brandão. Nessa acepção de realismo mágico, o autor cria situações insólitas ou sobrenaturais que não remetem a símbolos pré-industriais nem recebem uma explicação, ainda que contrariem, e muito, as leis naturais do universo criado pelo autor. Além dos contos de Loyola, a novela "A metamorfose", de Franz Kafka também encontra nessa definição o seu melhor lugar. Aliás, "A metamorfose" é, até onde sei, o primeiro exemplar de fantástico alegórico da história da literatura.

E por se tratar de um ensaio sobre o fantástico alegórico, faz-se necessário explorar aqui também uma concepção justa de alegoria.

O mais óbvio a respeito da concepção de alegoria é partir da etimologia: alegoria significa "falar uma coisa de outra maneira". Não é o bastante. Maria 
Zenilda Grawunder em seu livro "A palavra mascarada - sobre a alegoria" faz um percurso histórico desde as origens do termo e das aplicações deste recurso nas artes, passando pela concepção de Walter Benjamin sobre o mesmo assunto e porque o emprego da alegoria é tão difundido na modernidade. A princípio, Grawunder qualifica assim o texto alegórico:

O texto alegórico, por conceituação, institui-se no duplo textual de natureza analógica, pluralidade metafórica representativa de mais de uma realidade, histórica, ideal ou ficcional. Sendo assim, significativamente oferece mais de uma informação, oferece ao seu intérprete a possibilidade de exercício hermenêutico que ultrapassa os limites do emotivo, para envolvê-lo em sua unidade emotivointelectual, como ser histórico (GRAWUNDER, 1996, p. 28).

Ou seja, um texto alegórico possui uma primeira interpretação válida pois ele não é concebido para ter apenas seu segundo significado, como se fosse uma mensagem cifrada em código para iniciados - cheia de elementos simbólicos que vão se ligar a seu segundo ou terceiro significados. A chave para os significados além do primeiro não encontram-se apenas no mundo interior do autor, apesar de muito disso estar presente em sua obra, mas também em sua visão política e histórica de mundo.

Além disso, símbolo e alegoria não se confundem, pois o primeiro deve sempre remeter a um segundo significado na medida em que a alegoria tem um primeiro significado válido, conforme dito anteriormente.

O valor da alegoria no mundo moderno é inestimável. Em tempos de fácil reprodução das obras de arte, da produção em larga escala desses mesmos objetos artísticos, entre eles o livro, esse recurso literário torna-se a chave da perenidade: escrever uma obra alegórica é criar uma obra que permanecerá intrigando cada vez mais novos leitores ainda que a sua data de criação se distancie do momento em que é lida. Não apenas no tempo, mas também no espaço: sendo a linguagem alegórica de compreensão universal, diferentes povos de diferentes culturas podem (re)criar novas leituras para um mesmo texto, contribuindo para sua difusão e permanência.

Assim sendo, um texto alegórico não se prende apenas ao momento histórico em que foi criado, apesar de ser em momentos históricos marcados por regimes autoritários de controle rígido sobre a circulação da informações que escritores tenham encontrado na alegoria a sua única fonte de expressão e arma para vencer o silêncio, como é o caso de Ignácio de Loyola Brandão durante a ditadura militar brasileira (1964-1985), ou para se desvencilhar dos valores hipócritas de uma sociedade decadente e cada vez mais mecanizada, como é o caso de Franz Kafka na Europa do início do século XX. 
Estabelecidas as definições de fantástico e alegoria, cabe aqui uma pergunta: como é possível que essas duas diferentes possibilidades narrativas podem trabalhar em conjunto sem que uma anule a outra, visto que um texto alegórico aceita quaisquer acontecimentos, sejam eles sobrenaturais, insólitos ou absurdos, contanto que sua chave interpretativa possa ser aberta? Basta apenas voltarmos à definição de alegoria proposta por Walter Benjamin no momento em que diferencia esta de símbolo: a interpretação alegórica é o sentido segundo de um texto, porém este possui um primeiro sentido, que aqui é a narrativa fantástica, ou seja: temos a princípio um texto fantástico e, sobreposto a ele, uma chave alegórica para um segundo texto.

"A metamorfose", escrita por Franz Kafka em 1912, conta a história de Gregor Samsa, um caixeiro-viajante que acorda numa manhã transformado num inseto gigante. Apesar de sua condição, Gregor não se deixa abater e faz o possível para ir ao trabalho, pois está atrasado, mas não consegue ir além da porta do seu quarto. Essa incrível disposição de ir para o trabalho não provém de seu amor pela profissão, mas sim pela necessidade que Gregor sentia de manter os pais em casa descansando e poder mandar a irmã para a escola de música. Em sua nova forma, Gregor não apenas é impedido de trabalhar, como também de sair do seu quarto, onde fica até o dia de sua morte no esquecimento e na inanição, pois com sua ausência, sua família decide pôr mãos à obra e ganhar seu sustento com o seu próprio trabalho. Um grande alívio toma conta da casa: todos empregados, ganhando cada um seu salário sem precisar se incomodar com o inseto gigante no quarto de Gregor.

Em primeiro lugar, podemos garantir que se trata de uma narrativa fantástica - ou, mais exatamente, mágico-realista ontológica - por nos depararmos aí com um fenômeno (neste caso sobrenatural) que causa desconcerto aos personagens e que não se refere a símbolos pré-industriais e nem recebe uma explicação desde o começo até o fim da narrativa.

Essa novela em si tem uma estrutura muito curiosa, podendo até mesmo ser associada a processos experimentais muito comuns aos naturalistas: o que aconteceria se o personagem Y passasse pela experiência X? Kafka coloca ironicamente de mãos atadas o homem moderno, que precisa se afirmar como responsável e cumpridor de todos os seu deveres, e o que vemos acontecer é que esse homem não tenta restabelecer sua antiga forma, nem procura buscar uma resposta para seu enigma: quer apenas ir para o trabalho e continuar a exercer sua função social e familiar sem se importar com sua atual condição, a de um inseto.

E é justamente assim que Gregor se comportava antes da metamorfose, como um inseto. Trabalhando incansavelmente sem aproveitar os benefí- 
cios conseguidos com seu dinheiro, levando todos os seus recursos para a manutenção da colônia, representada aqui pela família de Gregor.

Observando o mundo que se formava no início do século $X X$, às portas da Primeira Guerra Mundial, vemos ali milhões de insetos europeus sendo explorados por seus patrões, ricos industriais que disputam centímetro a centímetro mercados consumidores ao redor do mundo. Vemos o começo do fragmentar da personalidade e da alma humanas que não encontram mais ao seu redor novos valores para essa nova sociedade que se forma e agregam para si os velhos como uma tábua de salvação em meio ao turbulento mar de mudanças. Como insetos, vários povos europeus, asiáticos, africanos e até mesmo americanos aceitam governos totalitários que lhes dão trabalho e mais trabalho para o sustento dessa ordem mundial. E mesmo após a Guerra, quando esses milhões de cidadãos perceberam que eram realmente insetos, criaturas abundantes de vida frágil e sem valor, preferiram permanecer insetos e eleger novos regimes totalitários.

É o que acontece com Gregor: mesmo após a metamorfose, ele permanece em seu quarto imundo esperando pelo dia de sua morte, sem jamais abandonar a casa da família que nem ao menos se lembra dele. Gregor prefere permanecer olhando para a janela que, mesmo aberta, não é atravessada, servindo apenas de consolo para seus sonhos de liberdade, quando tudo voltaria a ser como antes - o que não acontece, pois os bons tempos não voltam e Gregor não é capaz de vencer a tênue linha que o separa da sua real liberdade: uma nova possibilidade de vida e de buscas além das paredes do seu quarto. $\mathrm{O}$ homem-inseto representa esse homem do século XX sem esperanças, agarrado a migalhas de um passado extinto e sem coragem de encarar e adentrar o futuro. $\mathrm{O}$ medo da rejeição social e familiar fecha tanto os olhos de Gregor quanto os dos homens reais, fazendo deles meras criaturas utilitárias em função de um mundo maior onde todas as suas faces são rigorosamente iguais.

O Brasil não ficou à parte nesse processo histórico nem no literário. Infelizmente não é possível estabelecer até que ponto os autores brasileiros se abasteceram na fonte kafkiana ou se a difusão do emprego da alegoria na literatura fantástica é um fenômeno natural dentro de sociedades controladas por um sistema rígido e autoritário. A verdade é que um número considerável de escritores brasileiros do considerado "primeiro escalão" adotou esse recurso e, quando questionados acerca de suas leituras, muitos confessam, a exemplo de Murilo Rubião, nunca terem lido a obra do poeta de Praga antes de escreverem suas narrativas fantástico-alegóricas.

Ignácio de Loyola Brandão, por ter sido jornalista durante os anos de chumbo da história do Brasil, sentiu na pele o que era o controle do fluxo de informações. Viu colegas serem presos, deportados ou nunca mais os 
viu novamente após suas prisões. Enquanto isso, depositava no personagem Bernardo - reconhecidamente seu álter-ego, mas cujas reações diante dos fatos são bem diferentes das do escritor - a frustração de ver os sonhos da construção de um país melhor na figura do populista João Goulart (Jango) sendo destruídos por um golpe de Estado aplicado na madrugada de 31 de março para primeiro de abril (popularmente conhecido como "dia da mentira") de 1964. Em seu primeiro livro, "Depois do sol" (1965), Bernardo se sente flutuar entre as diferentes camadas da sociedade brasileira da época e se sente esmagado por perceber que todos aqueles de quem mais gostava acreditavam na mentira que "o perigo comunista foi afastado" e que "a democracia estava salva". Sozinho, ele amarga o fato de saber a verdade e viver desacreditado. A partir daí, Loyola começa a escrever romances, contos e novelas em que Bernardo aparece como um jovem jornalista que pretende ser escritor e, com suas obras, conscientizar os leitores do verdadeiro perigo que os brasileiros correm - uma temática muito comum entre os escritores da época, fenômeno descrito e analisado por Renato Franco em sua tese de doutorado sobre o romance brasileiro pós-64.

Entretanto é a partir de Zero que a alegoria passa a se tornar mais freqüente em seus livros, mas é em Cadeiras Proibidas e em $O$ homem que odiava a segunda-feira que o fantástico alegórico se apresenta em sua forma mais bem acabada. Podemos afirmar que ambos os livros tem uma mesma temática - a perplexidade diante da irrealidade do presente, convertida em símbolos que, dentro do texto, figurarão na construção de alegorias que remeterão não apenas às épocas correspondentes à sua produção como também à eterna condição humana.

Por se tratar de um livro cujos contos alegorizam um período já decodificado da História brasileira, evidencia-se a importância de começar por Cadeiras proibidas. Escrito após Zero, foi publicado antes devido às complicações que este sofreu para ser lançado - o livro mais famoso de Loyola foi lançado primeiramente em italiano e quando da sua publicação no Brasil, em 1975, o livro foi censurado e liberado apenas em 1979. Loyola conta que Zero foi finalizado em 1971 e Cadeiras proibidas em 1973 e que adotou a técnica alegórica para escapar da censura. A estratégia cumpriu seu objetivo, pois além de ser publicado antes de Zero, Cadeiras proibidas não foi proibido...

Cadeiras proibidas é um livro de contos dividido em oito seções (Cotidiano, Corpo, Clima, Mundo, Indagação, Descoberta, Ação e Vida) com número variável de contos dentro de cada uma. Todos os contos possuem um elemento comum que é o fato de apresentarem personagens que se deparam com situações ou fenômenos que abalam sua concepção de realidade. Esses fenômenos e situações não têm explicação, o que remete ao 
realismo mágico ontológico proposto por Spindler. Sua interpretação imediata não vai além do momento histórico vivido no momento da composição dessas narrativas, mas numa leitura mais atenta eles remetem aos eternos embates entre o homem e o mundo.

Um conto exemplar de Cadeiras proibidas a ser analisado aqui é "O homem do furo na mão”. Nesse conto, um homem normal, cidadão trabalhador, habitante de uma cidade grande como tantas outras no mundo, percebe, após um dia de trabalho, que em sua mão forma-se um furo que não lhe causa dor nem impossibilita seu uso. Mais do que isso, o homem se sente especial, diferente dos outros homens porque possui algo extraordinário que ninguém mais possui: um furo na mão. Sua mulher pede para que ele o esconda ou coisas horríveis podem acontecer. Ele não lhe dá ouvidos e segue para o trabalho no dia seguinte, quando decide exibir o furo, ato que não lhe rende atenção alguma por parte dos colegas. Ao chegar em casa, não encontra sua mulher, mas um aviso de que não vive com ele enquanto o furo existir. Assim sendo, ele desarruma toda a casa e, na manhã seguinte é desprezado pela faxineira que diz se recusar a trabalhar para quem tem furo na mão. No ônibus, é escorraçado pelo cobrador de, apanha de policiais na rua, é despedido ao chegar no emprego e é impedido até mesmo de se sentar num banco de praça. No fim do conto, o homem encontra vagabundos que na verdade são outros homens "furados" e decide tomar com eles um café ralo, de pó catado no lixo de bares, mas que serve para assentar o estômago (Loyola, 1997, p. 20).

Em primeiro lugar, esse é um conto fantástico, pois o fenômeno sobrenatural nele empregado não pertence ao cotidiano dos personagens e provoca o efeito de abalo, comentado anteriormente: ainda que o personagem tenha encontrado outros personagens com furo na mão, isso não quer dizer que receber misteriosamente um furo na mão seja um fato que pertença à ordem natural das coisas no universo criado por Loyola para esse conto. A prova disso é o tratamento dado àqueles que possuem o furo: abandono, degredo, exílio.

E o que significa ter um furo na mão? Popularmente, ter a mão furada é deixar cair as coisas, não conseguir mantê-las na mão por muito tempo. No entanto não parece ser essa a mensagem proposta pelo texto, apesar de o texto conter uma história com começo, meio e fim com um sentido primeiro: o homem sempre teve medo do desconhecido e furos que aparecem sem explicação nas mãos das pessoas sem danificá-las é identificado como amedrontador, motivo pelo qual essas pessoas são afastadas do convívio social. De acordo com a proposta de alegoria de Grawunder, essa é a primeira face interpretada para esse texto. Mas e a segunda, que faria dele um texto alegórico? A chave interpretativa para esse segundo conto encontra- 
se no próprio fenômeno sobrenatural e na forma como alegoricamente ele se liga com o mundo externo ao texto, ou seja, o mundo do escritor e o do leitor.

O momento histórico ao redor da composição desse conto é o período dos Atos Institucionais (ou AI's), por meio dos quais os generais-presidentes governavam o país e aumentavam seus poderes e o os de seu aparelho de repressão: a polícia. De acordo com a filosofia dos idealizadores dos AI's, era melhor perder a liberdade do que perder a segurança, pois era preciso manter a democracia e manter afastado o perigo comunista. Por meio de vários instrumentos legais o governo brasileiro limitou a circulação da informação; vários jornais, revistas e outros periódicos tiveram suas redações invadidas e editores, redatores, jornalistas e repórteres presos, exilados ou mortos. O mais gritante desses casos foi o assassinato de Vladimir Herzog, jornalista da Rede Cultura de Televisão , que foi preso, torturado e morto em 1975. A versão oficial dos fatos é a de que Herzog teria se suicidado, enforcando-se com sua gravata, presa no alto de uma cela de um metro e meio de altura. Comentaristas zombam dessa versão alegando que teria sido mais fácil morrer se Herzog tivesse engolido suas meias.

Esses e outros fatos sem explicação, faziam do cotidiano brasileiro uma sucessão de eventos insólitos, pois as versões oficiais mudavam de acordo com as refutações. Pode-se citar como exemplo uma passagem de Feliz ano velho, narrativa pessoal de Marcelo Rubens Paiva:

"No dia 20 de janeiro de 1971 era feriado no Rio, por isso dormi até mais tarde. De manhã, quando todos se preparavam para ir à praia (e eu dormindo), a casa foi invadida por seis militares à paisana, armados com metralhadoras. Enquanto minhas irmãs e as empregadas estavam sob mira, um deles que parecia ser o chefe, deu uma ordem de prisão: meu pai deveria comparecer na Aeronáutica para prestar depoimento. Ordem escrita? Nenhuma. Motivo? Só deus sabe" (PAIVA, 1983, p. 60).

Além do pai, a mãe também tinha sido levada em prisão, tendo, no entanto, sido solta duas semanas mais tarde, sorte que o pai não teve:

"Naquela época, a censura da imprensa não estava tão rigorosa e todos os dias saíam artigos nos jornais:

ONDE ESTÁ RUBENS PAIVA?

O Governo dizia que ele não se encontrava preso. MAS COMO NÃO ESTAVA PRESO, SE SUA MULHER VIU A FOTOGRAFIA DELE NO ÁLBUM DA PRISÃO?

A resposta era cínica e covarde: 
Fantástico e alegoria em A mão perdida na caixa de correio...

\section{A MULHER DE RUBENS PAIVA NUNCA ESTEVE PRESA,} NEM SUA FILHA.

Mas eles cometeram uma gafe. Meu pai, quando preso, foi guiando o próprio carro, que ficou estacionado no quartel da Barão de Mesquita. Mais tarde, uma tia minha foi recolher o carro, e os caras deram um recibo com um timbre do Exército.

MAS SE RUBENS PAIVA NÃO ESTAVA PRESO, O QUE SEU

CARRO ESTAVA FAZENDO ALI?" (PAIVA, 1983, p. 62)

Após três tentativas de habeas corpus baseadas nesse documento, o Exército deu a nova versão dos fatos:

“SEGUNDO INFORMAÇÕES DE QUE DISPÕE ESTE COMANDO, O CITADO PACIENTE, QUANDO ERA CONDUZIDO PARA SER INQUIRIDO SOBRE FATOS QUE DENUNCIAM ATIVIDADE SUBERSIVA, TEVE SEU VEÍCULO INTERCEPTADO POR ELEMENTOS DESCONHECIDOS, POSSIVELMENTE TERRORISTAS, EMPREENDENDO FUGA PARA LOCAL IGNORADO..."

Em outras palavras, ele tinha fugido. Foi a versão mais idiota que já inventaram, mas o que fazer? Logo depois veio a censura da imprensa sobre o caso (PAIVA, 1983, p. 63).

O relato de Marcelo Rubens Paiva não retrata um caso isolado da época e essas justificativas artificiais para o exercício da autoridade do Governo brasileiro é o que inspirou os contos de livros como Cadeiras proibidas. Entretanto, Loyola não trata apenas das autoridades que abusam do seu poder, censurando a imprensa, mas também da criação de uma "lei do silêncio”, segundo a qual é proibido dar acolhida aos subversivos ou o infrator também seria considerado como tal - o motivo pelo qual todos evitam os homens com furo na mão, dizendo não querer se envolver.

Dentro desse contexto do controle da informação, da censura sobre a imprensa, uma interpretação possível para o furo na mão é a própria informação inédita: um furo de reportagem, um furo jornalístico, uma notícia que será dada em primeira mão por apenas uma empresa, canal ou jornal. Nesse momento histórico, ter uma informação valiosa - e a informação valiosa aqui é aquilo que o Governo ditatorial não queria que fosse divulgado - era motivo de perseguição por parte das autoridades e de isolamento por parte dos pares ou outros cidadãos comuns que não queriam ser vítimas da mesma perseguição.

O mesmo recurso técnico ficou guardado por algum tempo até Loyola empregá-lo novamente em 1999, no livro de contos $O$ homem que odiava a 
segunda-feira. Composto por cinco contos escritos com a técnica do fantástico alegórico remetendo ao momento histórico em que são compostos (as questões do fim do século $\mathrm{XX}$ ), considero esse livro não apenas um marco, como também uma obra-prima do gênero fantástico.

O conto de mesmo nome do livro, narra a história de um homem que nos fins de domingo apresenta sintomas de uma doença provocada pela proximidade da segunda-feira e que só o abandonam quando a terça-feira desponta. Visando encontrar uma solução para o seu problema, o homem que odiava a segunda-feira inicia um movimento para extingui-la do calendário, indo às ruas em busca de apoio popular, pedindo às pessoas que participem de seu abaixo-assinado e freqüentem uma reunião na qual seriam debatidas estratégias para combater esse dia nefasto. Entretanto, poucas pessoas acreditam na sua idéia e a onda de partidários que o homem pretendia arrebanhar não se forma - o que não o impede de continuar sua luta.

Uma primeira questão se impõe ao ler este conto: a doença do personagem é real ou imaginária? De acordo com o médico que o examinou detalhadamente, ele era portador do vírus MondayMonday, que ataca seus portadores às segundas-feiras. Assim sendo, a doença, dentro do universo do conto, é real. Porém, como pode um vírus ter data para atacar e para parar? Apenas vírus de computador funcionam dessa maneira, manifestando-se apenas em datas específicas, como o famigerado vírus de computador "Michelangelo", que revela sua presença nos sistemas informatizados apenas no dia do aniversário do pintor renascentista. Sugerem ao homem que ele fique em casa às segundas-feiras e compense esse dia no domingo. Mesmo assim, o dia do reinício da semana, qualquer que seja ele, traz-lhe o mal-estar como se fosse a própria segunda-feira. Isso leva a crer que esse homem esteja sendo massacrado não pela segunda-feira em si, mas pela repetição inócua do tempo: a vida moderna, apesar de todas as inovações técnicas e mudanças no comportamento social, continua sendo uma vida dentro de ciclos fechados de tempo, nos quais as pessoas têm sua vida totalmente controlada e regrada. O que há nesse personagem é um sentido além dos demais que the permite ver a nocividade dessa vida cíclica e mostra que é preciso quebrar esse ciclo para seguir em frente, rumo a um tempo em que os homens não precisem mais repetir incessantemente seus atos e feitos, cometendo os mesmos erros geração após geração.

Os demais contos também apresentam cada um sua faceta desse mundo globalizado e contraditório em que vivemos: a perda da capacidade de comunicação entre as pessoas ("KersgatóiNula! KersgatóiNula!"), a solidão coletiva ("O mistério da formiga matutina), a perda da identidade e da individualidade ("As cores das bolinhas da morte"), o poder do tempo, a repetição eterna dos acontecimentos e a perda da noção do tempo ("O ho- 
mem que odiava a segunda-feira"). O último deles, não na ordem do livro, "A mão perdida na caixa de correio" é o que concentra praticamente todos esses conceitos com um agravante: a descartabilidade da vida humana.

O conto diz respeito a um escrivão que, na hora do seu almoço, numa segunda-feira (dia em que todas as histórias do livro começam), resolve ir até uma caixa de coleta depositar sua carta com cupons para participar de um concurso e ganhar um prêmio. Ao tentar forçar a entrada da sua carta na caixa, sua mão se desprende do punho e fica lá dentro também, sem cortes ou derramamento de sangue, como se pudesse naturalmente ser removida por desencaixe. O escrivão, ao invés de tentar reaver a sua mão arrebentando a caixa com seu canivete suíço, acha que cometerá o crime de destruição de propriedade privada e de violação postal e decide esperar pela coleta. Enquanto isso devaneia a respeito do fato, achando que todas as partes do corpo poderiam ser desatarraxadas e comutadas:

"E se todas as partes do corpo fossem removíveis? De repente, solta-se a perna, o joelho, a coxa, a barriga. Que maravilha ser a cabeça e olhar pedaços do próprio corpo espalhados. E se todos tiverem essa possibilidade e se dedicarem a trocas? Quer uma perna por um braço? Gosto mais do seu braço. Quer um peito estufado? Essa não! Quem vai querer uma barriga como a sua? Leve minha cabeça, me empreste a sua, por uns dias. Não vá me perder a cabeça, por favor! Um goleiro alugará mais braços. Com quatro nenhuma bola entra. Jogadores de basquete, vôlei, tênis, pianistas, lavadores de pratos, lutadores de boxe, bateristas de bandas, todos serão beneficiados pelos quatro braços. Crianças poderão tomar quatro sorvetes de uma só vez. Amantes terão mãos para todos os tipos de afagos. Para ler um livro ou cuidar de um bebê, que maravilha! Digitadores poderão alugar vários braços, trabalhando com diversos computadores. O bom será alugar outras cabeças, para não confundir trabalhos. Quem nunca usa a cabeça - e são tantos - poderão cedê-las para serviços beneficentes, exercendo utilidade pública. Um problema: assaltantes terão mais armas na mão, desvantagem para nós!” (LOYOLA, 1999, p. 35).

Acusado de estar fazendo propaganda para algum tipo de produto, pois as pessoas não acreditam em sua história, o escrivão decide dormir ali enquanto a coleta não chega. Na manhã seguinte ele acorda com a batida da porta da perua da coleta e não consegue alcançá-la. Ele segue para a seção de achados onde é atendido por um funcionário que é a encarnação da burocracia, tão criticada e ridicularizada na obra loyolana quanto os personagens abusam do poder que têm em Cadeiras proibidas. Por fim, o es- 
crivão decide ir até a Expedição, no Chora Menino (as histórias se passam na São Paulo de 1999) onde encontra outro funcionário pior do que o anterior, pois este desconfia que o homem sem mão seja um fiscal, vindo para surpreendê-lo lendo a correspondência extraviada antes que ela fosse incinerada. Ao certificar-se de que ninguém viria procurar pelo escrivão, o funcionário estrangula-o e coloca-o num saco de correspondência extraviada rumo à incineração. A mão é encontrada por uma funcionária que a princípio pensa em receber uma recompensa ao devolvê-la, mas que ao chegar em casa desiste disso e joga a mão para o cachorro.

O fenômeno que faz desse conto uma narrativa fantástica é obviamente a mão que se desprende do punho do personagem como se tivesse sido feita para isso. A história se desenrola num espaço que é o simulacro da cidade de São Paulo no momento histórico em que o conto foi escrito, ou seja, em 1999. Nesse espaço e nesse tempo tal fenômeno não pertence à ordem natural das coisas, mas para quem não viu a maneira como a mão se separou do braço, acredita que o escrivão seja apenas mais um mutilado entre tantos no mundo.

A mão, é reconhecidamente o símbolo da habilidade do homem, da sua capacidade de realizar proezas, ou seja, a mão é a mais antiga ferramenta humana: a partir do momento em que o homem se tornou capaz de andar sobre dois pés, liberou suas mãos para evoluir e reinar sobre todos os outros animais, podendo com ela atirar pedras, paus, manipular objetos ou construí-los para as diversas atividades que desenvolveu ao longo de sua existência. Logo, perder a mão para um ser humano é perder sua habilidade, é perder sua capacidade de fazer coisas que o diferenciam de outro animal.

No entanto, essa alegoria vai mais longe: o dono dessa mão não é um homem comum, mas um escrivão, um homem que ganha sua vida com sua mão e fazendo algo que até mesmo outros seres humanos ainda hoje são incapazes de fazer: escrever. Mesmo sendo escrivão e cumprindo sua função, o personagem é alvo de críticas por parte dos colegas de trabalho:

"Quando o primeiro computador chegou, foi entregue a outro funcionário, um espertalhão sem prática de cartório, apenas bom digitador. O chefe ainda advertiu: 'Se cuide você! Esses livros velhos e incômodos vão se acabar levando a tua raça junto. Ninguém mais escreve à mão'. Tinha sido um dia triste. Não escrever à mão. Por que não se pode ter computadores e livros? E se faltar energia elétrica? Não tinha acabado de acontecer o blecaute no país inteiro? E se viesse outro, durasse semanas?" (LOYOLA, 1999, p. 39)

E mais adiante: 


\begin{abstract}
"Não passava de um escrevente. Nem precisavam mais dele, ouvira dizer que ele devia pedir aposentadoria por invalidez. Imaginem, escrever nos livros. Os livrões de registro eram tão bonitos, davam seriedade ao cartório. Imensas pratelerias e aqueles livros de 55 centímetros de altura, negros, solenes. Talvez por isso se sentisse desajustado. Não há mais solenidades" (LOYOLA, 1999, p. 45).
\end{abstract}

Essas passagens demonstram que a perda da mão é apenas uma conseqüência natural da desvalorização que ela vinha sofrendo: revoltada com sua própria condição, a mão decide abandonar seu todo, no qual ela não tem mais razão de existir e se refugia onde não pode ser molestada, numa caixa de correio cheia de cartas escritas à mão! O que justificaria essa interpretação seria, primeiro, o fato de o conto se chamar "A mão perdida na caixa de correio" e não "O homem que perdeu a mão na caixa de correio", o que seria mais natural vindo de um autor como Loyola; e, segundo, o fato de haver pelo menos um precedente na narrativa fantástica de membro do corpo que se rebela e abandona seu conjunto: $O$ nariz, de Gógol.

$\mathrm{O}$ uso da mão para escrever, abandonado em função do uso do computador, ferramenta dos novos tempos, do século XXI que começaria em breve, remete à gradual substituição do homem na linha de produção pela máquina. Como se isso não bastasse, o homem já não consegue mais viver sem as máquinas e essa cultura do simples apertar de botão faz com que a necessidade de uma mão bem treinada - pois um escrivão deve ter uma excelente caligrafia para preencher os solenes livros do cartório - desapareça, já que qualquer parte do corpo humano pode apertar um botão. Fatos como esse, o excesso de comodidades na vida moderna diminui a capacidade do homem de resolver sozinho os seus problemas mais triviais e um deles está bem diante de nós nesse conto: que juiz condenaria à prisão um homem que arrebenta uma caixa de correio para reaver sua própria mão dentro dela? Ao invés de pensar nisso, o escrivão prefere devanear sobre o que aconteceria se todas as partes do corpo do homem pudessem ser destacadas e comutadas com outros homens.

Pelo que o conto deixa a entender, a grande maioria das cartas que chegam ao destino são as cartas comerciais, pois as pessoais (raras) extraviamse, tornando-se objeto da cobiça do funcionário dos correios que as lê antes de elas serem destruídas. Aqui duas interpretações cabem perfeitamente. A primeira, é que as comunicações por carta, que têm um destinatário específico, nada mais são do que comércio, propaganda, manifestações do mundo capitalista e globalizado em que vivemos. A segunda é a curiosidade com que os seres humanos espiam a intimidade alheia: com certeza, o funcionário da Expedição não lia cartas comerciais, pois estas não têm como 
se extraviar. Ao ler as cartas pessoais dos remetentes, o funcionário está se intrometendo na vida alheia, invadindo sua intimidade, demonstrando seu total desrespeito pelo outro ser humano que ele desconhece completamente. E a prova cabal desse desrespeito por parte desse funcionário é o assassinado que comete. Quando se certifica de que ninguém virá reclamar a ausência do escrivão, ele não teme estar retirando a vida de alguém, mas livrando-se das punições a que seria submetido se fosse descoberto.

Por fim, o escrivão que vai em busca de sua mão, da materialização da sua essência, que é escrever à mão (tanto quanto à forma de inseto de Gregor, em Kafka, corresponde o seu comportamento de submissão à colônia), acaba se perdendo e nunca mais encontrando nem sua mão nem seu caminho de volta ao tempo em que sabia quem era e tinha a mais absoluta certeza do que era capaz de fazer. Uma triste constatação de que até mesmo o direito de buscar uma resposta para indagações e problemas pessoais está morto em função da harmonia global.

\section{BIBLIOGRAFIA}

BENJAMIN, Walter. Alegoria e drama barroco. In:__Origem do drama barroco alemão. São Paulo, Brasiliense, 1984.

BESSIÈRE, Irène. La littérature fantastique: la poétique de l'incertain. Paris, Larousse, 1974.

BRANDÃO, Ignácio de Loyola. Cadeiras proibidas. São Paulo, Global, 1997. O homem que odiava a segunda-feira. São Paulo, Global, 1999.

FINNÉ, Jacques. Littérature fantastique: un essai sur l'organisation surnaturelle. Bruxelas, Éditions de l'Université de Bruxelles, 1980.

FRANCO, Renato. Itinerário do romance pós-64: “A festa”. Edunesp, São Paulo, 2001.

FAUSTO, Bóris. História do Brasil. Edusp, 1994.

GRAWUNDER, Maria Z. A palavra mascarada. Ed. da UFSM, 1996.

KAFKA, Franz. A metamorfose. Companhia das Letras, São Paulo, 2001.

PAIVA, Marcelo R. Feliz ano velho. Brasiliense, 1983.

SPINDLER, Willian. Magic realism: a typology. In: Forum for modern language studies, vol. XXXIX, no. 01. págs 75-85. University of Essex, Essex, 1993.

TODOROV, Tzvetan. Introdução à literatura fantástica. Perspectiva, São Paulo, 1975.

VAX, Louis. Thèmes, motifs et schèmes. In:___ La séduction de l'étrange. PUF, Paris, 1965. 